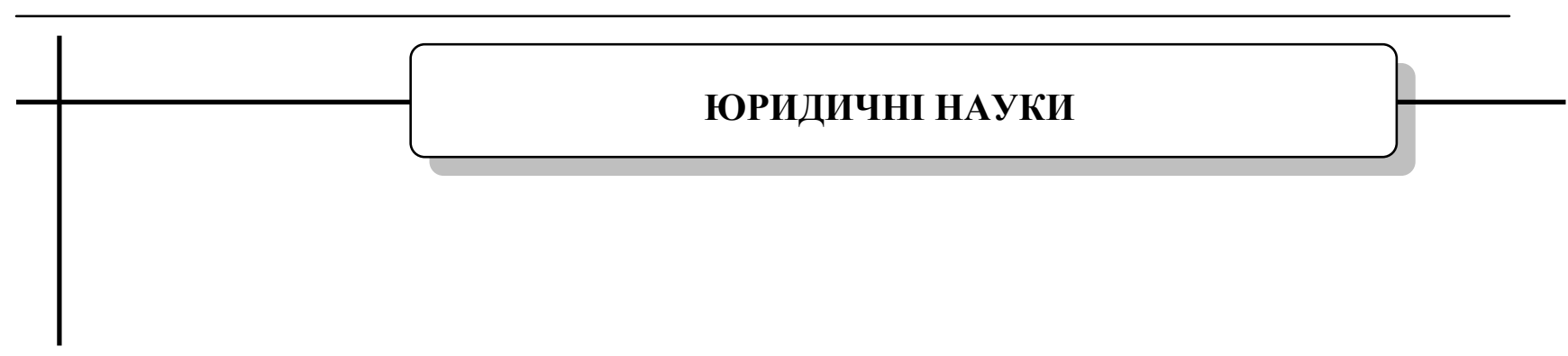

UDC 341.1/8

DOI: $10.15587 / 2313-8416.2016 .85846$

\title{
THE ANALYSIS OF CONTEMPORARY LEGAL STANDARDS AND PRINCIPLES IN MASS MEDIA PERFORMANCE: A DOMESTIC AND INTERNATIONAL LAW OVERVIEW
}

\author{
A. Lytvinenko
}

\section{АНАЛІЗ СУЧАСНИХ ПРАВОВИХ СТАНДАРТІВ І ПРИНЦИПІВ ДІЯЛЬНОСТІ ЗАСОБІВ ЗМІ: ПІДХІД 3 ТОЧКИ ЗОРУ НАЦІОНАЛЬНОГО ТА МІЖНАРОДНОГО ПPABA}

\section{А. А. Литвиненко}

The article is devoted to an overall analysis of Ukrainian and European Union legal standards of mass-media performance. It's tentatively subdivided into 3 parts and encompasses a scrutiny of several domestic laws, Council of Europe and EU institutions acts featuring brief analysis of the legislation from other states from the legislation of other European states

Keywords: mass media, broadcast, censorship, case law, statutory law, data protection

Стаття присвячується загальному аналізу украӥнських та європейських правових стандартів діяльності засобів 3МІ. Вона умовно поділена на 3 частини та охоплює розгляд кількох актів національного законодавства, нормативні акти Ради Європи та інституиій СС, включаючи короткий аналіз з законодавства з законодавства інших країн Свропи

Ключові слова: засоби ЗМI, мовлення, цензура, прецедентне право, статутне право, захист даних

\section{Introduction}

In every state, the mass media performance maxims are backed by a vigorous legal backbround, which is a massive of laws and bylaws regarding the press, television and radio broadcast, news agencies and cinematography. Apart from domestic legislation, there is a coarse handful of standards and principles, elaborated by the Council of Europe and the European Union institutions throughout the last decades. By their nature, such standards and principles are moderately complicated and are broadly reflected in the national legislation of European countries. One of the most sophisticated aspects in this topic gyrates around the balance between Art. $8(\S 1)$ and Art. 10 ( $(1)$ of ECHR, both of which are declared as fundamental human rights in complicance with the provisions of this Convention. Whereas the former proclaims a human's right to privacy, the latter engrafts the right to freedom of expression. The principles of equipoise are often laid down quite broadly in statutory law, so it's quite a cunning issue how to discover it. Some researchers stick to case law in the praxis of the European Court of Human Rights or other international courts, while the others try to designate principles using statutory law. Each approach has got it's swings and roundabouts. At the same time, both can benefit to the overall verbatim.
Taking into account that some legislations (including the Ukrainian one) expound it in quite a wide scope, these gaps are to be occluded by narrow principles irrespective of their descent.

\section{Source and literature overview}

The source baggage for the article is rather volumetric and is pretty much based on various legislative acts [1-8] as well as international instruments (CoE recommendations, EU Directives [9, 10], the '89 European Convention on Tranfrontier Television etc. [11]). The sources also feature a handful of British Information Commissioners Office (ICO) opinions regarding personal data usage in journalist activities [12]. In addition, several notions were taken from the author's recent article that deals with personal data conceptual vehicle [13]. Overally, the article observes contemporary principles of information dissemination in mass media performance (albeit one document dates back to 1970 [14]) and some angles of balancing between freedom of expression and the right to privacy. The article is attached to informational law, which is one of the most underresearched law disciplines in Ukraine. This discipline is one of the youngest law sphreres to date and is subject to a crucial research interest as it often does not possess an adequate response to- 
wards modern challenges in mass media performance and journalist activities.

\section{Aim and research problems}

The article is aimed at conducting an analysis of media performance legal standards in domestic and EU legislation as well as introduces some notions regarding journalist and media performance $v s$ personal data protection. The problems, outlined in this treatise are stated as underwritten:

1. To investigate on contemporary Ukrainian legislation regarding mass media performance and analyze what principles are encompassed, to what extent are international standards fulfilled.

2. To find gaps in domestic legislation and to hallmark them (they are also stripped for future research and treatises).

3. To analyze international instruments grazing mass media performance and outline the principles of mass media performance in compliance with Council of Europe and EU institutions.

4. To conduct a brief overview of the issue of data protection within mass media performance. Since domestic law treats this topic quite broadly the problem is to find and give a more detailed and narrow explanatory by engaging case law and statutory law of other countries.

4. The legal standards of mass media performance and the issue of individual data protection in journalist affairs

First and foremost, let us outline the principles of mass media performance in Ukraine's legislation. The freedom of expression in Ukraine is anchored in p. 2 of art. 34 of Ukraine's Constitution, which states everyone is to enjoy freedom to assemble, withhold, exploit and impart data. Under the aforegiven provisions, a massive of legislation regarding the mass media performance is laid down. These provisions are strictly tied with several primordial international agreements, as the ECHR (Art. 10 (§1)) or ICCPR (Art. 19) and reflect their normative content quite precisely. At the same time, the derogation of this right in exclusionary cases is foreseen in p. 3 art. 34 of the Constitution, which we're going to discuss later.

The carcass of Ukrainian legislation regarding media performance consists of various laws and bylaws, from which the main are the following:

- Ukraine's Law No. 2782-12 “On the printed mass media" (1992), initially dubbed and augmented from USSR's Law No. 1552-I “On press and other mass media" (1990) [1, 15];

- Ukraine's Law No. 3759-12 “On television and radio broadcast" (1993) [2];

- Ukraine's Law No. 74-95BP “On informational agencies" (1995) [3];

- Ukraine's Law No. 538/97BP “On Ukraine's National Council on television and radio broadcast" (1997) [4];

- Ukraine's Law No. 9/98BP “On cinematography" (1998) [5].

The aforegiven list is certainly not explicit, but encompasses the general media performance regulation.
Some less important laws in this field, as Ukraine's Law No. 2657-12 "On information" (1992), overally regulates social affairs in the information field [16]. So, we can claim that the massive of legislation is quite substantial, but at the same time it features certain gaps. Until now, there is no law dealing with digital means of distributing news at all, albeit some minor bylaws regarding digital mass media resourses do exist [16]. The electronic mass media isn't observed in the scope of Ukraine's Law "On the printed mass media" [1] and is briefly mentioned in p. 1 of Art. 29 of Ukraine's Law "On informational agencies", where computer networks are, inter alia, stated as means of dissemination by information agencies [3]. Still, we should tentatively consider that the principles used within conventional mass media, will be applicable in the digital media, too. Therefore, let us proceed towards the principles of mass media performance and their legal side.

1. Freedom of speech: an equipoise angle. It is guaranteed under the aforementioned provisions of the Constitution of Ukraine, but still has got a number of exemptions which are utmostly reflected and expounded in the Deliverance of Ukraine's Constitutional Court No. 2pп/2012 from 20.01.2012 upon the lodgement of the district council of Zhashkiv (Cherkasy oblast), which transceived it to the Court for a proper explanatory of Art. 32 and 34 of the Constitution [6]. Under paragraph 4 of point 4 of the motivational section of the Deliverance, the derogation of one's right to freedom of information ensues as underwritten:

- national security and territorial standalone;

- public order and crime avoidance;

- public health security;

- protection of one's reputation and the rights of other people;

- confidential data divulgance;

- justice unbiasity [6].

As the Court rules in para. 6 of point 4 of the motivational section, this list is ultimate and the right to freedom of information can not abuse the rights of physical persons and legal entities, involving the right to privacy, that is anchored in the Constitution as well [6]. Under para. 2 of point 1 of the resolutive section of the Deliverance, the Court states that assemblage, maintenance, usage and distribution of confidential data without a consent is an interference to private life, bearable only in exceptional cases. However, the Court does not detalize the points or give out any conjectural criteria of such exemption ensue. Some scholars advise attributing them to case law [13], mainly in the praxis of the European Court of Human Rights (with which we're going to deal briefly in the last subpart of the article), but statutory law of some states (e.g. the British [7]) is also eligible to figure them out. Still, since case law is often codified in legislative acts, it's quite concordant to investigate both.

2. Censorship inhibition. As we can notice from the first principle, the freedom of press and information looks like a set of tare weights. The censorship is banned under p. 3 of Art. 15 of Ukraine's Constitution. The Art. 15 explanatory depicts a pluralism notion, dilated on all spheres of social life which the state is meant to promote. This principle regarding mass media performance is ex- 
panded in the domestic legislation more broadly. Under p. 2 of Art. 2 of Ukraine's Law "On the printed mass media", the evolvement and financing of state bodies, organizations or official positions for press censorship is banned as well as the necessity of tentative material tradeoff with state bodies, enterprises, organizations and civil association unless they were a party of an interview or they were the authors of the disseminated information [1]. The same goes to television and radio broadcast: in compliance with p.p. 1-2 of Art. 5 of Ukraine's Law "On television and radio broadcast", the censorship is banned and the TV and radio- enterprises are standalone in to determine the media content [2]. Of course, the excession of such freedom is also not allowable, with which we're going to deal in Principle 3. As a last remark for Principle 2, the censorship of scientific research results is also inhibited under p. 3 of Article 308 of Ukraine's Civil Code [17], but it has got some issues regarding personal data usage in them, which can not violate one's right to privacy (e.g. some aspects regarding the usage of statistical information which contains some personal data).

3. Averting the freedom of information abuse. Albeit the freedom of expression and information is a fundamental human right, no state can guarantee that the mass media workers will be absolutely conscientious. Therefore, the legislation establishes a set of screwplugfuses to prevent the freedom of expression abuse. This involves some standards in press and informational agencies, television and cinematography. Let us begin with the press abuses, which are laid down as underwritten in compliance with p. 1 of Art. 3 of Ukraine's Law "On printed mass media" thereafter:

- summons to a coup, destroying the constitutional order of the country or forced authority replacement, violence and teracts;

- the propaganda of war, violence and brutality (which is likely to be tied with para. 2 of Art. 3 of the 1978 UNESCO Declatation on Fundamental Principles [...] [18]);

- kindling racial, national and religious hostility (which docks with the abovegiven provisions of the 1978 UNESCO Declaration [18]);

- disseminate pornography, and other (as given in $\mathrm{p}$. 3 of Art. 2 of Ukraine's Law "On informational agencies") obscent data which undermines the social morality [3];

- after a series of 2015 amendments [1, 3], it is banned to propagandize communist and Nazi regimes and their symbols;

- the press can not interfere into one's private life (it will be discussed in the third subpart in detail) and harm one's respect and dignity, protected by the Art. 24 of Ukraine's Constitution.

Some other taboos are set in the performance of journalists, TV and radio broadcasts. Yes, in compliance with p. 7 of p. 3 of Art. 26 of Ukraine's Law “On printed mass media", it's inhibited to an acting journalist to disseminate information in commercial purposes which contain advertisement or the manufacturer's contacts [1]. These notions were expanded in a draft law "On the protection of journalists' professional performance" by a $7^{\text {th }}$ convocation deputee, Mykola Katerynchuk, which was registered in the Parliament in early 2013 but recalled in
March, 2013 [19]. As of point 3 of p. 1 and p. 2 of Art. 6 of the draft law, journalists are prohibited to execute any concealed advertisement, especially for their or their relatives purposes and exploit concealed insertions in reports, documentaries or films which are to make impact on one's consciousness (e.g. "the 25th frame") [19]. It is also forbidden to use a servant's position in the interests of politicians or political parties, where the media servant is enrolled [19]. If the journalist operates in the locations of armed conflicts, he's obliged not to disseminate any data regarding combatant plans or interfere into any incidents (point 11 of p. 1 Art. 5 of the draft law) [19]. Such a principle would correlate with the 1977 Additional Protocol to the Geneva Conventions of August 12, 1949 [20]. According to Art. 79 (§ 1-2) of the 1977 Additional Protocol, journalists are treated as civilians (hence, noncombatants) and are protected under the series of the Geneva Conventions if they do not conduct any actions, which are inconsistent with the civilian status, hallmarked in Art. 50 (§ 1) of the 1977 Additional Protocol [20]. The point 3257 of the Protocol's 1987 Commentary emphasizes that journalists maintain such status even if they accompany definite armed forces [21]. That goes - a journalist must stay neutral. However, as mentioned above, these provisions did not come into force as the draft law was recalled [19].

Transgressing to TV, radio and cinema, there's a number of taboos, too. In compliance with p. 1 of Art. 57 of Ukraine's Law "On television and radio broadcast", the requirements to dissemination and generation of media content are attached to the editorial statute of the broadcasting organization [3]. According to the provisions of p. 4 of Art. 57 of Ukraine's Law "On television and radio broadcast", this statute (which is to be public under p. 6 of Art. 57) has to set out the demands regarding, inter alia, dissemination of information about political parties, socially unshielded people (e. g. the disabled, religious groups), national and sexual minorities, the data marked as confidential and information regarding violence [3]. Obviously, depicting such materials must not harm anyone's dignity or other rights. Other exemptions that are laid down in p. 2 of Art. 6 Ukraine's Law "On television and radio broadcast" of are quite similar to the press issues, and include some specifities, as the ban of such services, as fortune-telling, cartomacy and alternative medicine, excessive violence, pornography distribution and some others [3]. The broadcasting enterprises are to fulfill the presumption of innocence under point " 3 ” of p. 1 of Art. 59 of Ukraine's Law "On television and radio broadcast", that is, they must abstrain from estimative notions regarding crime conviction before it is officially proved [3].

A handful of issues are also tangent to cinema. Para. 3 of p. 3 of Art. 15 of Ukraine's Law "On cinematography" exempts the distribution of films, the content of which propagandizes war, features excessive violence, neglects humanism, praises pernicious habits and depicts disrespect to culture and morality [5]. Well, this is all grazing the freedom of information and press abuse.

4. Pluralism and state support of media. Although the principles of pluralism are not specified in the 
Ukrainian legislation in detail (e.g. like they're laid down in CoE Recommendation (99) 1 [22]), there are some notions which are to be hallmarked. In accordance with p. 3 of Art. 10 of Ukraine's Law "On state support of mass media and social protection of journalists", the mass media are deemed equal in their rights regardless of the property form [23]. P. 4 of Art. 10 constrains monopoly in the media sphere (in vivo, there is no real media monopoly in Ukraine, but an oligopoly of some media corporations instead, that is, small-scale broadcasters usually can not achieve large audience). The framework for the financial support of media is quite limited. According to p. 1 of Art. 3 of the abovementioned law, financial support could be lodged for the media which:

- encompass just specific audience groups (infants, young people and the disabled);

- scientific periodicals of universities which possess at least the $3^{\text {rd }}$ accreditation grade;

- fiction literature periodicals;

- media, vectored at promoting languages and cultures of national minorities [24].

What as to media concentration, there are no detailed provisions considering it except from the given above.

The international standards of mass media performance in Europe evolved from the late 1960s. The CoE Resolution 428 (1970) was the first one to set out some guidelines of mass media performance and contained a "Declaration on mass media and human rights", assembled on principles, that were elaborated at a 1968 Salzburg symposium on this subject $[24,25]$. The main points are hereafter according to the Res. 428 (1970) provisions:

1. The right to freedom of expression and information is to be spread on mass media ( $\$ 2$ of part A);

2 . The application of press independence has to be foreseen by the law. Any possible restrictions could be imposed by a court decision, but not by executive power ( $\$ 4$ of part A);

3. Direct censorship is to be inhibited and this ban should be spread on mass media production (press, TV and radio broadcast, news, or other transceived information - actually, the chronicles are mentioned as an example in Res. 428). Any conjectural limitations could occure in compliance with Art. 10 (\$2) ECHR. There shouldn't be any state control on the media content with an exception of these provisions. ( $§ 5$ of part A);

4. The independence of mass media should be protected against monopolies. No enterprises can hold a monopoly in mass media. There shouldn't be a government-owned monopoly, too. (§ 7-8 of part A);

5 . The states are to provide freedom for foreign media correspondents. At the same time, they are obliged to give out precise information. ( $\$ 9$ of part A);

6 . The performance of journalists has to be adequate. It involves a professional preparation, elaborating codes of ethics and founding press councils and commissions that would investigate the performance violations ( $\$ 1$ of part B) [25].

Omiting various declarative documents, a set of extended principles within mass media freedom and hu- man rights issues was depicted in Resolution No. 2 of the $4^{\text {th }}$ European Ministerial Conference on Mass Media Policy (which was carried out in Prague, Czech Republic on December 7-8, 1994) [26]. It contained 8 principles of mass media performance, which go as follows:

1. The journalists inform the society about the performance of authorities and private sector entities for it to form a custom opinion. They are also to let people express their thoughts to inform private and public bodies about them. It is important for the media workers to subject the performance of public bodies to a critical observation (as stated in Principle II of Resolution No. 1 of the abovestated conference, media is to be a kind of a rostrum of a public discussion which would encompass a multitude of opinions) [26];

2. The activities of media workers in printed and digital media is grounded on Art. 10 ECHR;

3. The journalist practice promotes democracy if:

a. The access to a journalist profession is granted;

b. The editorial independence is virtual, especially with respect to public bodies or any pressure, that would be drained of private or public entities;

c. The access to official information is virtual;

$\mathrm{d}$. The source of information, used by the media is to be confidential.

4. The interference of public bodies into the mass media performance is to be limited and figure in compliance with Art. 10 ( $(2)$ of ECHR, be necessary in a democratic society and has to correspond with such a necessity. Such restrictions have to be hallmarked in the legislation, they should be defined narrowly and they have to be proportionate to the aims gained for them [26];

5 . The public authorities have to promote mass media freedom constituents, such as systems of journalist professional preparation, a multilateral dialog between mass media workers and the authorities as well as setting up and maintaining appropriate social security measures for mass media workers, who perform their duties in various hazardous situations [26];

6. Mass media performance has to be adequate and to keep within the law and human rights. The mass media workers have to treat their duties with responsibility [26];

7. The $7^{\text {th }}$ principle features a number of these "adequate" notions:

- to respect the right of public to be informed precisely about facts and events;

- to obtain their materials lawfully;

- a fair depiction of information, averting from baseless private life violation or indictments;

- to correct the information, which turned out to be roughly inaccurate;

- to keep professional secret regarding the sources of information;

- non-ecouragement of violence, hatred, intolerance and discrimination.

8. The public authorities when observing the aspects laid down in principle 7 are to be modest and recognize self-regulation of mass media performance (including the codes of ethics) [26].

Some of these principles were broadened later. The concept of pluralism was evolved in CoE Recom- 
mendation (99) 1, adopted on January 19, 1999 [22]. The main particles involved the following:

- the States are to input so-called thresholds to limit monopoly or press concentration, which is to be authorized by the legislation (Section I);

- the States are to create freedom for digital broadcasting (Section II);

- the States are to encourage broadcasting diversity and media independence (Section III p. 3 and Section IV);

- the States can undertake supporting measures for the broadcasters or media in some cases, e.g. the enterprises which face difficulties or local press (Section VI) [22].

The notion of source secrecy, as mentioned in Principle 7 of Resolution II of the $4^{\text {th }}$ European Ministerial Conference on Mass Media Policy (1994) was evolved in the CoE Recommendation (00) 7, adopted on March 8, 2000 [27]. A number of it's notions evolved from a case in the practice of the European Court of $\mathrm{Hu}-$ man Rights, namely Goodwin vs United Kingdom (March 27, 1996) [28]. In para. 39 of the judgement, the Court ruled that "...protection of journalistic sources is one of the basic conditions for press freedom, as is reflected in the laws and the professional codes of conduct in a number of Contracting States and is affirmed in several international instruments on journalistic freedoms [...] Without such protection, sources may be deterred from assisting the press in informing the public on matters of public interest. As a result the vital public-watchdog role of the press may be undermined and the ability of the press to provide accurate and reliable information may be adversely affected" [28]. That is, the Court recognized that the right not to disclose the source of information, which is operated by the mass media is included into Art. 10 (§ 1) ECHR, which is reflected in para. 3 of CoE Recommendation (00) 7 [27]. The equipoise between "the public interest" and "source secrecy" is elaborated in para. 15 (b) of CoE Recommendation (00) 7 and para. 37 of the Court's judgement in the '96 Goodwin vs United Kingdom case [27, 28]. According to these provisions, the source of the information is not entirely decisive for the public, therefore, it is not generally necessary to unfold it, especially if the "source" forbad this. Under para. 18 (points i-iv) of the Recommendation, such information types include:

- the name of the source (taking into account that this source is definitely a human) and other "typical" personal data - address, telephone and telefax number, the name of the employer, photographs and spectrograms;

- circumstances under which the data was obtained (location, type of correspondence);

- some unpublished content given to the media worker - it stands for facts, photos or other recordings which could indicate the identity of the source (which could be rendered as "indirect" personal data - that is, such facts are not considered to be a kind of conventional personal data featured in the paragraph above, but it would give enough notice to determine someone for an acknowledged person). As I outlined in my recent article [13], an explicit definition of "personal data" and it's scope margins haven't been elaborated since the term appeared in the mid-to-late 1960s. Therefore, there is no ultimate insight what could be considered as personal data itself. In such a legal and technical maze, it would be ample for a journalist just not to disclose the "indicators" [27];

- other personal data obtained and produced within the work of media workers. Such could be found in telephone call lists, travel vouchers and others [27].

The matter of such guidelines is - journalists and mass media in general often has to work with personal data. However the processing procedures prescribed by the domestic legislation are usually derogated by the statement that they're not utilized for the purposes of mass media, artistism, scientific research etc, but one has to keep in mind that inaccure exploitation (but note, definitely not processing [13]) could bring to negative consequences.

The topic of advertisement and transborded broadcast is also reflected in EU law [10, 11]. The European Convention of Tranfrontier Television, adopted in 1989, anchored a set of guidelines regarding transborder broadcasting, performance of broadcasting enterprises abroad and the rules of advertisement. The EU Council Directive 89/552/EEC (1989) which gives details on several topics $[10,11]$. All-in-all, these instruments regulate transborder TV broadcast. Under Art. $6(\S 1)$ of the Convention, foreign broadcasters are to receive a special license, which is given by an issuing body; their duties are to be prescribe in this license or a contract that would be concluded. The broadcasters are to provide data about the enterprise (Art. 6 \$) and are obliged not to disseminate media which contains obscene materials, eroticism and excessive violence (Art. $7 \S 1$ ). The 89/552/EEC also outlines that the Member-States are obliged to undertake measures to avert any materials of the broadcasters, which are under their jurisdiction, which would harm physical, spiritual and moral development of adolescents (Art. 22 §) [10, 11]. If such programs are broadcasted uncoded, there has to be a sonic warning (Art. 22 \$3). Under Art. 22a of the Directive the Member-States have to ensure that the broadcasted materials do not incite to race, gender, religious and national discrimination [10]. Under Art. 9bis $(\$ 1)$ of the 1989 Convention, the States can restrain exceptional foreign broadcasting regarding any concrete news or events. However, such events can not be random and the States can work out a list of such events which are protected to domestic and local broadcasters [11].

These instruments provide guidelines for advertisement, which is briefly laid down as follows:

- The advertisement has to be clear and distinct (Art. $10 \S 1$ of the EEC Directive), it mustn't abuse the interests of consumers, induce adolescents to purchase goods or conclude contracts (Art. 11 of the 1989 Convention), the advertisement also can not contain any discriminatory features (Art. 12 of the Directive) [10, 11];

- Concealed advertisement or one with techniques which make impact on subliminal consciousness, is banned (under Art. $10 \S 4$ of the Directive and Art. $13 \S 2$ of the Convention) $[10,11]$, news dictors can not read advertisement texts (Art. $13 \S 4$ );

- Advertisement is broadcasted between the programs, but it is eligible to insert it into the programs if 
they do not impact the general content or abuse the owner's rights (Art. $14 \S 1$ of the Convention);

- The advertisement of cigarettes or other tobacco products is forbidden (Art. 13 of the Directive and Art. $15 \S 1$ the Convention); the advertisement of alcohols is quite restricted. It is not allowed to tell that alcohol production has got any healing or stimulating impact, features or promotes physical achievements, it can't be associated with driving, promote alcohol overuse, or depict sobriety as a negative quality (Art. $15 \S 2$ of the Convention) [11];

- It is inhibited to advertise medicines, which can not be obtained without a recipe under Art. $15(\S 3)$ of the Convention;

- The last substantial principle encompasses sponsorship, which is reflected in both instruments. The Directive 89/552/EEC gives these guidelines in detail. It is overally known that a lot of TV programs are created with a participation of sponsor(s). If so, the sponsor organizations are to be strictly designated as sponsors at the beginning or the end of the program by announcing them or putting the label on tape (Art. $17 \S 1 \mathrm{~b}$ ). Sponsors are not allowed to trample the media workers regarding the place of their advertisement (Art. 17 §1a). Such labels can not provoke to purchase any production directly or indirectly (Art. 17 \$1c). Cigarette and tobacco manufacturers are exempt from sponsorship (Art. 17 §2). Manufacturers of medical production or medicines are allowed to become sponsors, but the advertisement of their products is granted only under the consent of a public body of the Member-State (Art. 17 §3). News programs and political talk-shows are exempt from the possibility of sponsorship (Art. 17 §3) [10,11].

The problem of privacy and personal data usage in mass media performance. Mass media staff often face working with personal data. From the legal point of view, working with personal data for a journalist or other mass media personell is a very delicate substance, since most domestic laws treat this topic quite broadly. Point 2 of p. 2 of Art. 25 Ukraine's Law "On personal data protection" (adopted in 2010 to implement the Council of Europe ETS 108 Convention) emphasizes that the rules of appropriate data handling are not spread on journalistic and some other creative purposes (these notions were briefly analyzed in my preceding article [13]). At the same time, the media crew is to keep within the equipoise of private life respect and freedom of expression. The matter is, if they could really figure it out, as it's a riddle even for lawyers. The Ukrainian law does not specify the criteria for such equipoise, so media personnel is really likely to find the tare weighs by themselves, but at the same time, it has to correspond with the overall exemptions issued by legislative acts regarding press, television \& radio broadcast and cinema, which are widely observed in the article. To represent it even more narrowly, additional notions from case law and statutory law can be exploited. Both of them are quite wholesome to build up the theory. Let's start with the "tares", which were elaborated in the praxis of the $E u$ ropean Court of Human Rights. Since it's praxis involves thousands of cases, a number of bifuraction points were developed around mid-1980s [29]. The following points are used in Art. 8-11 ECHR cases:

1. If the petitioner complains regarding his rights violation, does the matter fall within the margins of the actual right? If it does not, no violation is found by the Court [29];

2. Is there an actual limitation on the exercise of one's right? If there is not, than there was no violation [29];

3 . Is such restriction imposed by some public authority? If not, no violation is found;

4. Is such restriction authorized by the legislation? If not, than the violation occurs;

5 . Does the restriction serve accurately for the reasons, laid down in Art. $10(\S 2)$ ? It demands accurate examination, but it's quite rare the Court to find it did not (which meant a violation) [29];

6. Did this restriction serve for the needs of " $a$ democratic society"? It is a cunning principle and demands a thorough analysis. Some issues could also be observed by $80 \mathrm{~s}$ CoE Recommendations regarding data protection (e.g. 87 (15), 97 (18)) [29].

A handful of other principles are also used. Yes, the Court can examine the matter of public interest (which is observed in $\mathrm{CoE}$ Recommendation (00) 7 and the preceding cases) which has got it's own criteria, but it would take too long to deal with them in one article. As mentioned in my preceding article, one of the personal data discipline "fathers" Willis Ware, in the book "Records, Computers and the Rights of Citizens" (1973) emphasized, that case law can not be a foremost agent in developing rules regarding data protection, as their opportunity to generate any legal principles is limited by the nature of the litigation [30]. But anyway, the court praxis could be used to amend laws. It is obvious, that it should be executed as mass media personnel are seeminigly unalike to conceive case law or use such knowledge in their professional performance. Therefore, case law could be a supplementary tool in the theory, but definitely not a primordial one (some scholars could argue about it).

Tracing back to statutory law, Art. 67 of the French Data Protection Act (Loi 78-17, adopted on January 6, 1978) features a similar position to the Ukrainian, but a more detailed one. Most conventional data maintenance does not fall within journalist purposes with an exception of notifying the supervisory body (which is a structure named "CNIL" - a shortcut for the Commission Nationale de l'Informatique et des Libertés) by filling a declaration of such usage in compliance with Section 1 of Art. 22 of the French data protection law. [9] Under Art. 67, other margins are drawn by the French Civil and Criminal Code, that is, mass media personnel is to work entirely in the legal framework that is applied in the legislation regarding data privacy and related issues [9]. Quite a similar approach could be found in British Law: under Subsection 1 (a) of Section 32 of the British Data Protection Act 1998 c. 29, the provisions of data maintenance have exemptions, inter alia, for journastic, literary or artistic material. However, it does not discharge mass media agents from registering in ICO as data controllers in compliance with Subsection 1 of Section 17 of the Data Protection Act. [32] Such regisration has go a fee of 35 GPB. [33] It is illegal to obtain or disclose, or 
share with other people personal information, which was gained without the concent of the data controller (Section 55 of the DPA). [32].

The 2010 BBC Editorial Guidelines [7, 31] set a number of issues of working with personal data and other privacy aspects. Section 7.1 of the Guidelines represents features regarding the equipoise between public interest and intrusion to privacy that goes as following: private behavior, data, conversations etc are not to be brought into the society unless there is a public interest that overrides it (the formula will be given a little further). As of the Guidelines, such cases include, but are not confined to:

- depicting and detecting crime;

- illustrating unsocial conduct;

- showing corruption or injustice;

- revealing someone's pronounced incompetence or negligence;

- protecting people's health and safety;

- prevent people from being desinformed by a person or organization;

- revealing information that could help people to conceive or decide on matters of public importance [7].

The 2010 Guidelines also include notions regarding filming non-public places or specific groups of society. As of Section 7.4.2., the BBC crew operates openly by default (unless they have approval for concealed recording). The Guidelines foresee that the BBC crew would have to obtain informed consents to film and broadcast. That is, not to violate the organization's and people's privacy, they are to obtain these consents to film private property (Sec. 7.4.5), two separate consents on filming non-public places (schools, hospitals, prisons) - one for filming and another for broadcast (Sec. 7.4.4.) and obtain an informed consent within filming children (under 16) or socially-vulnerable people by their consent in person or their parents, relatives or guardians (Sec. 7.4.7.) Semi-public places, however, do not fall under this policies as it refers to public interest test (Sec. 7.4.5.). Since BBC maintains personal data of the contributors, it can't be genuinely handed over to third parties without a consent of the contributor himself. If such consent is unavailable, the lodgement is to be referred to a senior editorial officials who could consult the BBC Information Policy and Compliance (a BBC department) for help. If a concent is obtained, the contract would oblige the third party to exploit personal data only for purposes stipulated between the contributor and the BBC. [7]

Certainly, there is much more interesting to tell, but the volume of one article is not ultimate. So, tracing back to Ukrainian legislation, the best way of a journalist to figure out the equipoise and practice is to:

- analyze the legislation regarding printed mass media, TV and radio broadcast and search for exemptions and examples of freedom of expression abuse. These would be the actual margins outlined in statutory law;

- take into account the domestic journalist Code of Ethics and search for foreign ones to compare or to inquire more;

- always keep in mind, that public interest has to be clearly pronounced;

- do not rely on separate case law examples or fully adhere to case law principles. They are decent by themselves, but their criteria may vary from case to case;
- inquire about the principles of mass media performance which are laid down in international instruments;

- keep within data protection principles if he was a coarse data controller.

Therefore, using non-case law technique, we proved that guidelines for mass media personnel regarding personal data and privacy do exist and are terse enough to adhere to them.

\section{Results}

As it had been expected, the given article achieved the main goals by depicting a comprehensive treatise on the main legal standards of media performance in Ukraine and abroad. The author would like to outline, that most principles adopted in international instruments are reflected in national legislation (at least, legally). However, a virtual gap regarding electronic means of mass media still exists and this problem can obviously bear more cunning issues, which will be discussed in the future articles. The article also illustrated some case law principles which could be taken as a template to amend laws and bylaws.

\section{Conclusions}

The article was partially designated to become a next "volume" of the preciding one, as it also covers several data protection issues. But still it is an independent treatise, as data protection topic is not the heading one in it, albeit the data protection angles in mass media performance are also quite a complicated stuff to deal with the article evokes one of the facets of the data protection discipline and creates the surface for posterior studies.

Nota bene. A couple of remarks for the reader from the author.

1. The names of Ukraine's legislative acts are a verbatim translation of original ones. To browse them, please check the reference list;

2 . The text of the given article has got several assessed opinions which belong to the author. The author does not intend to obtrude any of them. The reader is free to object and not to agree with them;

3 . The article features several abbreviations, which are frequently used in legislative acts and scientific literature. The ECHR stands for the '50 European Convention of Human Rights and ICCPR - for International Covenant on Civil and Political Rights (1966). The shortcut of ECHR is not used to designate the European Court of Human Rights, since they coincide with the abbreviation of the Convention.

\section{References}

1. On printed mass media in Ukraine [Text]. Verkhovna Rada Ukrainy, 1992. - № 2782-12. - Available at: http://zakon5.rada.gov.ua/laws/show/2782-12

2. On television and radio broadcast [Text]. - Verkhovna Rada Ukrainy, 1993. - № 3759-12. - Available at: http://zakon3.rada.gov.ua/laws/show/3759-12

3. On informational agencies [Text]. - Verkhovna Rada Ukrainy, 1993. - № 74/95-BP. - Available at: http://zakon2. rada.gov.ua/laws/show/74/95-\%D0\%B2\%D1\%80

4. On Ukraine's National Council on television and radio broadcast [Text]. - Verkhovna Rada Ukrainy, 1997. - 
№ 538/97-BP. - Available at: http://zakon2.rada.gov.ua/laws/ show/538/97-\%D0\%B2\%D1\%80

5. On cinematography [Text]. - Verkhovna Rada Ukrainy, 1998. - № 9/98-BP. - Available at: http://zakon2. rada.gov.ua/laws/show/9/98-\%D0\%B2\%D1\%80

6. Rishennja konstitucijnogo sudu Ukrainiu spravi za konstitucijnim podannjam Zhashkivs'koi rajonnoi radi Cherkas'koi oblasti shhodo oficijnogo tlumachennja polozhen' chastin pershoi, drugoi statti 32, chastin drugoi, tret'oi statti 34 Konstitucii Ukrainy [Text]. - Konstitucijnij Sud, 2012. - № 2рп/2012. - Available at: http://zakon3.rada.gov.ua/laws/show/ v002p710-12

7. BBC Editorial Guidelines [Electronic resource]. British Broadcasting Corporation. - 2010. - Available at: http:// www.bbc.co.uk/editorialguidelines/guidelines/

8. On Advertisement [Text]. - Verkhovna Rada Ukrainy, 1996. - № 270/96-BP. - Available at: http://zakon3.rada. gov.ua/laws/show/270/96-\%D0\%B2\%D1\%80

9. Loi informatique et libertes [Electronic resource]. Available at: https://www.cnil.fr/sites/default/files/typo/ document/Act78-17VA.pdf

10. The EU Council Directive [Text]. - Verkhovna Rada Ukrainy, 1997. - 89/552/EEC. - Available at: http://zakon3. rada.gov.ua/laws/show/994_446

11. The European Convention on Transfronier Television [Text]. - Verkhovna Rada Ukrainy, 1989. - № ETS (132). - Available at: http://zakon5.rada.gov.ua/laws/show/994_444

12. Data protection and journalism: a guide for the media [Electronic resource]. - Information Commissioner's Office. - 2014. - Available at: https://ico.org.uk/media/1552/dataprotection-and-journalism-media-guidance.pdf

13. Lytvynenko, A. Approaches towards judicial and scientific definition of the 'personal data protection' discipline maxims, their explanatory and correlation [Text] / A. Lytvynenko // ScienceRise. - 2016. - Vol. 8, Issue 1 (25). - P. 6673. doi: $10.15587 / 2313-8416.2016 .75461$

14. Declaration on mass communication media and Human Rights [Text]. - Parliamentary Assembly, 1970. - № 428. - Available at: http://assembly.coe.int/nw/xml/XRef/XrefXML2HTML-en.asp?fileid=15842\&lang=en

15. On press and other mass media [Text]. - Verkhovna Rada Ukrainy, 1990. - № 1552-1. - Available at: http:// zakon2.rada.gov.ua/laws/show/v1552400-90

16. On information [Text]. - Verkhovna Rada Ukrainy, 1992. - № 2657-12. - Available at: http://zakon2.rada.gov. ua/laws/show/2657-12

17. Civil Code of Ukraine [Text]. - Kyiv: Palywoda A., 2015. - P. 107-108.

18. Declaration on Fundamental Principles concerning the Contribution of the Mass Media to Strengthening Peace and International Understanding, to the Promotion of Human Rights and to Countering Racialism, apartheid and incitement to war [Text]. - UNESCO Portal, 1978. - № 4/9.3/2. - Available at: http://portal.unesco.org/en/ev.php-URL_ID=13176\&URL_DO $=$ DO_TOPIC\&URL_SECTION=201.html

19. On protection of professional performance of journalists [Text]. - Verkhovna Rada Ukrainy, 2013. - № 158-VII. Available at: http://w1.c1.rada.gov.ua/pls/zweb2/webproc4_1? pf3511 $=45601$

20. Protocol Additional to the Geneva Conventions of 12 August 1949, and relating to the Protection of Victims of International Armed Conflicts (Protocol I) [Text]. - International Committee of the Red Cross. Treaties, States Parties and Commentaries, 1977. - № 79. - Available at: https://ihl-data bases.icrc.org/applic/ihl/ihl.nsf/Article.xsp?action=openDocumen $\mathrm{t} \&$ documentId=6E95E63184FD05C8C12563CD0051E0FB

21. Protocol Additional to the Geneva Conventions of 12 August 1949, and relating to the Protection of Victims of International Armed Conflicts (Protocol I) [Text]. - International
Committee of the Red Cross. Treaties, States Parties and Commentaries, 1977/1987. - Available at: https://ihl-databases.icrc.org/ applic/ihl/ihl.nsf/Comment.xsp?action=openDocument\&document $\mathrm{Id}=\mathrm{CBD} 4507 \mathrm{E} 8159 \mathrm{EBE} 1 \mathrm{C} 12563 \mathrm{CD} 00436 \mathrm{EC} 4$

22. On measures to promote media pluralism [Text]. Council of Europe, 1999. - No. R (99) 1. - Available at: https://search.coe.int/cm/Pages/result_details.aspx?ObjectID=0 $9000016804 \mathrm{fa} 377$

23. On state support of mass media and social protection of journalists [Text]. - Verkhovna Rada Ukrainy, 1997. № 540/97-вр. - Available at: http://zakon3.rada.gov.ua/laws/ show/540/97-\%D0\%B2\%D1\%80

24. Data Protection and the Media, Study [Text]. Strasbourg: Council of Europe Press, 1991. - P. 19-21.

25. Robertson, H. Privacy and Human Rights. Papers by experts on an issue by growing importance under the auspices of the European Convention of Human Rights [Text] / H. Robertson. - Manchester: Manchester City Press, 1973. - P. 380-383.

26. 4th Ministerial Conference on Mass Media Policy [Text]. - Council of Europe, 1994. - Available at: https://wcd. coe.int/com.instranet.InstraServlet?command $=$ com.instranet.CmdB loGet $\&$ InstranetImage $=411463 \&$ SecMode $=1 \&$ DocId $=517420 \&$ Usage $=2$

27. Explanatory memorandum [Text]. - Council of Europe, 2000. - No. R (00) 7. - Available at: https://rm.coe. int/CoERMPublicCommonSearchServices/DisplayDCTMContent? documentId $=09000016805 \mathrm{e} 2 \mathrm{c} 13$

28. Case of Goodwin vs United Kingdom [Text]. - European Court of Human Rights, 1996. - № 17488/90. - Available at: http://hudoc.echr.coe.int/eng\#\{\%22itemid\% 22:[\%2200157974\%22]\}

29. UK Information Commissioner Study Project: Privacy \& Law Enforcement [Text]. - The Legal Framework, 2004. - No. 4. - Available at: http://ec.europa.eu/justice/news/ events/conference_dp_2009/presentations_speeches/KORFF_Douw e_b.pdf

30. Ware, W. Records, Computers and the Rights of Citizens [Text] / W. Ware. - Washington, 1973. - 346 p. Available at: https://www.justice.gov/opcl/docs/rec-com-rights.pdf

31. BBC Editorial Standards [Electronic resource]. British Broadcasting Corporation. - Available at: http://www. bbc.co.uk/editorialguidelines/

32. Data Protection Act [Electronic resource]. - Legislation.gov.uk. - Available at: http://www.legislation.gov.uk/ ukpga/1998/29/contents

33. Register (notify) under Data Protection Act [Electronic resource]. - Information Commissioner's Office. Available at: https://ico.org.uk/for-organisations/register/

\section{References}

1. On printed mass media in Ukraine (1992). Verkhovna Rada Ukrainy, 2782-12. Available at: http://zakon5.rada. gov.ua/laws/show/2782-12

2. On television and radio broadcast (1993). Verkhovna Rada Ukrainy, 3759-12. Available at: http://zakon3.rada.gov. ua/laws/show/3759-12

3. On informational agencies (1993). Verkhovna Rada Ukrainy, 74/95-BP. Available at: http://zakon2.rada.gov.ua/laws/ show/74/95-\%D0\%B2\%D1\%80

4. On Ukraine's National Council on television and radio broadcast (1997). Verkhovna Rada Ukrainy, 538/97-BP. Available at: http://zakon2.rada.gov.ua/laws/show/538/97-\%D0\% B2\%D1\%80

5. On cinematography (1998). Verkhovna Rada Ukrainy, 9/98-BP. Available at: http://zakon2.rada.gov.ua/laws/ show/9/98-\%D0\%B2\%D1\%80

6. Rishennja konstitucijnogo sudu Ukrainiu spravi za konstitucijnim podannjam Zhashkivs'koi rajonnoi radi Cherkas'koi oblasti shhodo oficijnogo tlumachennja polozhen' chas- 
tin pershoi, drugoi statti 32, chastin drugoi, tret'oi statti 34 Konstitucii Ukrainy (2012). Konstitucijnij Sud, 2-рп/2012. Available at: http://zakon3.rada.gov.ua/laws/show/v002p710-12

7. BBC Editorial Guidelines (2010). British Broadcasting Corporation. Available at: http://www.bbc.co.uk/editorialguidelines/guidelines/

8. On Advertisement (1996). Verkhovna Rada Ukrainy, 270/96-BP. Available at: zakon.rada.gov.ua/laws/show/270/96-вр

9. Loi informatique et libertes. Available at: https:// www.cnil.fr/sites/default/files/typo/document/Act78-17VA.pdf

10. The EU Council Directive (1997). Verkhovna Rada Ukrainy, 89/552/EEC. Available at: http://zakon3.rada.gov. ua/laws/show/994 446

11. The European Convention on Transfronier Television (1989). Verkhovna Rada Ukrainy, ETS (132). Available at: http://zakon5.rada.gov.ua/laws/show/994_444

12. Data protection and journalism: a guide for the media (2014). Information Commissioner's Office. Available at: https://ico.org.uk/media/1552/data-protection-and-journalism-media-guidance.pdf

13. Lytvynenko, A. (2016). Approaches towards judicial and scientific definition of the 'personal data protection' discipline maxims, their explanatory and correlation. Science Rise, 8 (1 (25)), 66-73. doi: 10.15587/2313-8416.2016.75461

14. Declaration on mass communication media and Human Rights (1970). Parliamentary Assembly, 428. Available at: http://assembly.coe.int/nw/xml/XRef/Xref-XML2HTML-en. asp?fileid $=15842$ \&lang $=$ en

15. On press and other mass media (1990). Verkhovna Rada Ukrainy, 1552-1. Available at: http://zakon2.rada.gov.ua/ laws/show/v1552400-90

16. On information (1992). Verkhovna Rada Ukrainy, 2657-12. Available at: http://zakon2.rada.gov.ua/laws/show/ 2657-12 107-108.

17. Civil Code of Ukraine (2015). Kyiv: Palywoda A.,

18. Declaration on Fundamental Principles concerning the Contribution of the Mass Media to Strengthening Peace and International Understanding, to the Promotion of Human Rights and to Countering Racialism, apartheid and incitement to war (1978). - UNESCO Portal, 4/9.3/2. Available at: http://portal. unesco.org/en/ev.php-URL_ID=13176\&URL_DO=DO_TOPIC\& URL_SECTION=201.html

19. On protection of professional performance of journalists (2013). Verkhovna Rada Ukrainy, 158-VII. Available at: http://w1.c1.rada.gov.ua/pls/zweb2/webproc4_1?pf35 $11=45601$

20. Protocol Additional to the Geneva Conventions of 12 August 1949, and relating to the Protection of Victims of International Armed Conflicts (Protocol I) (1977). International Committee of the Red Cross. Treaties, States Parties and
Commentaries, 79. Available at: https://ihl-databases.icrc.org/ applic/ihl/ihl.nsf/Article.xsp?action=openDocument\&documentId= 6E95E63184FD05C8C12563CD0051E0FB

21. Protocol Additional to the Geneva Conventions of 12 August 1949, and relating to the Protection of Victims of International Armed Conflicts (Protocol I). International Committee of the Red Cross. Treaties, States Parties and Commentaries, 1977/ 1987. Available at: https://ihl-databases.icrc.org/applic/ihl/ihl.nsf/ Comment.xsp?action=openDocument $\&$ documentId=CBD4507E8159EBE1C12563CD00436EC4

22. On measures to promote media pluralism (1999). Council of Europe, No. R (99) 1. Available at: https://search. coe.int/cm/Pages/result_details.aspx?ObjectID=09000016804fa377

23. On state support of mass media and social protection of journalists (1997). Verkhovna Rada Ukrainy, 540/97-вр. Available at: http://zakon3.rada.gov.ua/laws/show/540/97-\%D0\% B2\%D1\%80

24. Data Protection and the Media, Study (1991). Strasbourg: Council of Europe Press, 19-21.

25. Robertson, H. (1973). Privacy and Human Rights. Papers by experts on an issue by growing importance under the auspices of the European Convention of Human Rights. Manchester: Manchester City Press, 380-383.

26. 4th Ministerial Conference on Mass Media Policy (1994). Council of Europe. Available at: https://wcd.coe.int/com. instranet.InstraServlet?command $=$ com.instranet.CmdBlobGet\& InstranetImage $=411463 \&$ SecMode $=1 \&$ DocId $=517420 \&$ Usage $=2$

27. Explanatory memorandum (2000). Council of Europe, No. R (00) 7. Available at: https://rm.coe.int/CoERM PublicCommonSearchServices/DisplayDCTMContent?document $\mathrm{Id}=09000016805 \mathrm{e} 2 \mathrm{c} 13$

28. Case of Goodwin vs United Kingdom (1996). European Court of Human Rights, 17488/90. Available at: http://hudoc. echr.coe.int/eng\#\{\%22itemid\%22:[\%22001-57974\%22]\}

29. UK Information Commissioner Study Project: Privacy \& Law Enforcement (2004). The Legal Framework, No. 4. Available at: http://ec.europa.eu/justice/news/events/conference_dp_ 2009/presentations_speeches/KORFF_Douwe_b.pdf

30. Ware, W. (1973). Records, Computers and the Rights of Citizens. Washington, 346. Available at: https://www. justice.gov/opcl/docs/rec-com-rights.pdf

31. BBC Editorial Standards. British Broadcasting Corporation. Available at: http://www.bbc.co.uk/editorialguidelines/

32. Data Protection Act. Legislation.gov.uk. Available at: http://www.legislation.gov.uk/ukpga/1998/29/contents

33. Register (notify) under Data Protection Act. Information Commissioner's Office. Available at: https://ico.org.uk/ for-organisations/register/

Рекомендовано до публікації д-р юрид. наук, професор Микієвич М. М. Дата надходження рукопису 07.11.2016

Lytvynenko Anatoliy, Postgraduate student, Department of International Law, Ivan Franko National University of Lviv, Universytetska str., 1, Lviv, Ukraine, 79000

E-mail: kenguru25@yandex.ru

Литвиненко Анатолій Анатолійович, аспірант, кафедра міжнародного права, Львівський національний університет імені Івана Франка, вул. Університетська, 1, м. Львів, Україна, 79000

E-mail: kenguru25@yandex.ru 